\section{Case report of a new pathogenic variant of Aspergillus fumigatus isolated from Hipposideros cervinus (Chiroptera: Hipposideridae) in Sarawak, Malaysia}

\section{S.S. Jaya Seelan ${ }^{1} \&$ F.A. Anwarali ${ }^{2}$}

${ }^{1}$ Institute for Tropical Biology and Conservation, Locked Bag 2073, Universiti Malaysia Sabah, 88999 Kota Kinabalu, Sabah, Malaysia ${ }^{2}$ Department of Biological Sciences, Texas Tech University, Lubbock, Texas 79409-3131, U.S.A.

Email: ${ }^{1}$ avinash80us@yahoo.com

Zoosporic fungi are currently receiving a lot of attention with regards to emerging infectious and wildlife diseases. Fungal infection has been reported in humans and domestic animals worldwide, mostly studied in clinical isolates (Alekseev 2003; Zdenek 2004). There are fewer reports concerning wildlife diseases, especially among insectivorous and frugivorous bats in Sarawak, in Malaysian Borneo.

Recently, Seelan et al. (2008) found six species of Aspergillus isolated from 13 individuals of both insectivorous and frugivorous bats. Out of 23 individual bats observed, $13(56.5 \%)$ were identified as hosts for 17 fungus isolates, including $A$. restrictus, $A$. fumigatus, $A$. clavatus, $A$. japonicus, $A$. niger and $A$. sydowii. On physical examination of one insectivorous bat Hipposideros cervinus (Fawn Round Leaf Bat), it was noted that the bat had lesions near the ear openings, with a powdery surface on the skin parts. Scraping and swab samples from the lesion

Date of publication 26 March 2009

ISSN $0974-7907$ (online) | 0974-7893 (print)

Editor: Jacob V. Cheeran

Manuscript details:

Ms \# 02084

Received 23 October 2008

Finally accepted 24 February 2009

Citation: Seelan, S.S.J. \& F.A. Anwarali (2009). Case report of a new pathogeni variant of Aspergillus fumigatus isolated from Hipposideros cervinus (Chiroptera: Hipposideridae) in Sarawak, Malaysia. Journal of Threatened Taxa 1(3): 190191.

Copyright: (c) S.S. Jaya Seelan \& F.A. Anwarali 2009. Creative Commons Attribution 3.0 Unported License. JoTT allows unrestricted use of this article in any medium for non-profit purposes, reproduction and distribution by providing adequate credit to the authors and the source of publication.

Acknowledgements: We would like to thank Universiti Malaysia Sarawak (UNIMAS) and Texas Tech University (TTU) for giving us the opportunity to participate in Sowell-UNIMAS Expedition 2006 (refer to Anwarali et al. 2008). The authors are also grateful to Professor Maren Klich of the United States Agricultural Department (USDA), Professor Jens Frisvad Denmark Technical University (DTU) and Associate Professor Dr. Sepiah Muid of Unimas for providing various information on the Aspergillus species identification. We would also like to thank Associate Professor Dr. M.T. Abdullah from UNIMAS for sharing his insight on the ecology of bats in Borneo and all team members of TTU and Faculty of Resource Science and Technology, UNIMAS for their field assistance. This study was conducted with the kind permission of Sarawak Forest Department and Sarawak Forest Cooperation with permit number NPW.907.4.2 (1)-45 to M.T. Abdullah. The Economic Planning Unit, Prime Minister Department, Putra Jaya, Malaysia provided the permit for Faisal's team to conduct research in Sabah, Sarawak and Peninsular Malaysia is fully acknowledged. The recen survey on bats was partly supported by a grant from Mr. James Sowell to R.J. Baker and a FRG 01 (S07)595 2006(28) Unimas/21/09-0.1.2.5 (15) small grant to M.T. Abdullah.

OPEN ACGESS | FREE DOWNLOAD were taken for further investigation and characterization. The swab from the infected area was cultured on Sabaroud's agar and incubated at $37^{\circ} \mathrm{C}$. It was confirmed that the infection was due to Aspergillus fumigatus. The isolate (UNIMAS F009) is a thermophilic fungus with biochemical and morphological characteristics that differ from those reported by Raper \& Fennell (1965, 1977), and Klich (2002). A. fumigatus (pathogenic and thermophilic) was the first record isolated from the chiropterans in Sarawak, Malaysian Borneo. Furthermore, this isolate was found to be a new variant of $A$. fumigatus because it could thrive from $25^{\circ} \mathrm{C}$ to $65^{\circ} \mathrm{C}$, with an optimum temperature at $37^{\circ} \mathrm{C}$, producing a pink soluble pigment under Czapek's media only. The macro and micro morphology of this isolate are described as Klich (2002).

Macromorphology: Colony diameter on Czapek's Yeast Extract agar (CYA) attaining about $30-55 \mathrm{~mm}\left(7\right.$ days at $\left.25^{\circ} \mathrm{C}\right)$; colony growth very slow; conidia on this media were greenish; mycelium white; exudates absent; reverse uncolored; soluble pigment absent; texture floccose; sparse sporulation. On malt extract agar (MEA), colony growth was about 50-60 mm ( 7 days at $25^{\circ} \mathrm{C}$ ); conidial color was grey green; reverse pink; texture as on CYA25. On Czapek's agar, the colony color was green with white mycelia growing in patches; colony sectors were dividing into three more variants from this isolate. A soluble pink pigment was present when the $\mathrm{Cz}$ plate was kept at $37^{\circ} \mathrm{C}$. Colony growth on CYA37 was exceptionally rapid, sporulation was sparse; conidia color grayish-green. This isolate cannot grow at $5^{\circ} \mathrm{C}$, and is able to grow up to $65^{\circ} \mathrm{C}$.

Micromorphology: Conidial heads columnar; conidiophores uncolored, smooth-walled 350-600 x 6-10 $\mu \mathrm{m}$, pyriform to spathulate vesicles. Vesicles $10-25 \mu \mathrm{m}$ in diameter; uniseriate;

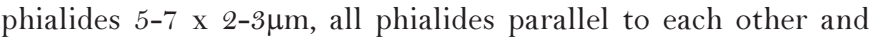
the conidiophore axis. Conidia globose to broadly ellipsoidal, smooth to finely roughned, 4-6 $4 \mathrm{~m}$ in diameter (Figure 1).

\section{Interspecific association}

There are three color morphs of H. cervinus, i.e. dark grey, yellowish-brown and bright orange (Payne et al. 1985), which might relate to differences in the niches that various individuals occupy (M.T. Abdullah pers. comm.). The host is well distributed in Sarawak, roosts in caves in large colonies and feeds in the forest understorey (Hall et al. 2004; Payne et al. $1985)$. With the cave temperatures of about $25^{\circ} \mathrm{C}$, dense cover and ambient forest temperature of about $27^{\circ} \mathrm{C}$ and humidity of $>85 \%$, the tropical rain forest in Sarawak provides a conducive environment for the growth of pathogenic fungi on wildlife. These conditions, combined with their roosting in large colonies in damp caves has resulted in bats becoming a favorable reservoir for different types of pathogenic mycoflora. Further work should be done to discover other potentially zoonotic mycoflora in wild mammals in Sarawak, Borneo.

\section{References}

Alekseev, A.N. \& H.V. Dubinina (2003). Multiple infections of tickborne pathogens in Ixodesspp. (Acarina: Ixodidae). Acta Zoologica Lithuanica 13: 311-321.

Anwarali, F.A., V.J. Swier, P.A. Larsen, S. Solari, K. Besar, M. Wahap, M.T. Abdullah, S. Ellagupillay, M. Marklarin \& R.J. Baker (2008). Using genetics and morphology to examine species diversity of old world bats: report of a recent collection from Malaysia. Occasional 

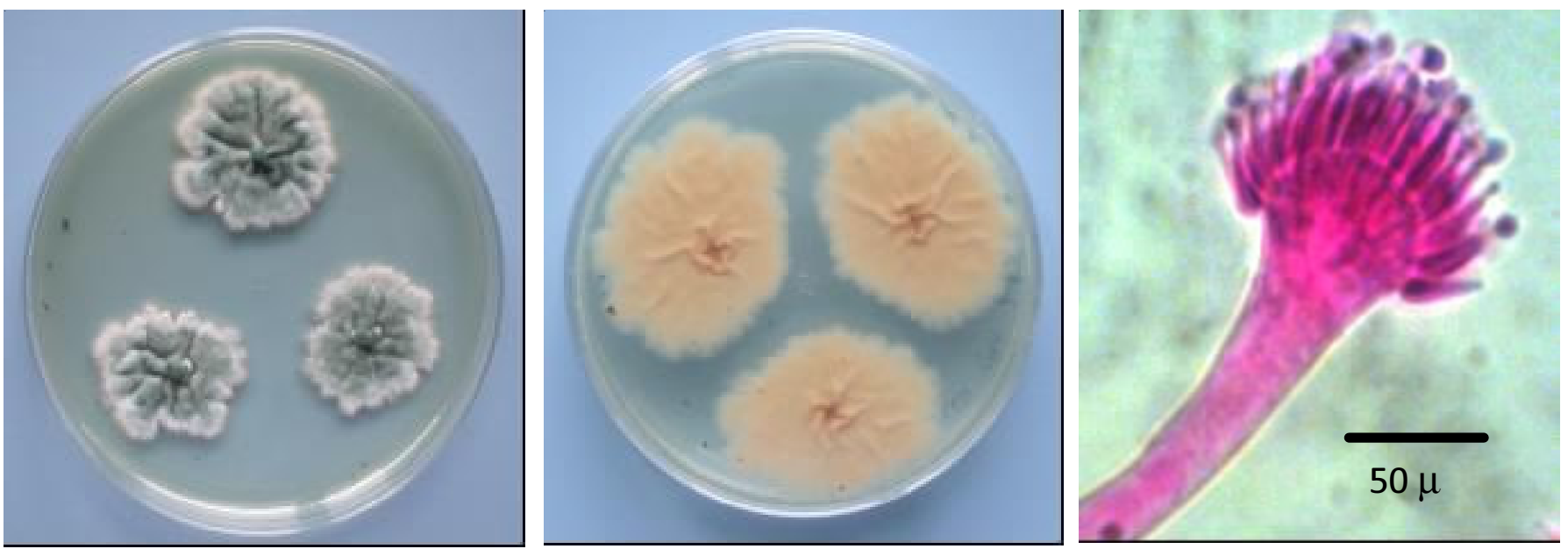

Image 1. (a) Colony growth of $\boldsymbol{A}$. fumigatus (UNIMAS F009) on Czapek's after seven days at $37^{\circ} \mathrm{C}$; (b) reverse plate; (c) uniseriate conidial head with thick conidiophore.

Papers of the Museum of Texas Tech University 281: 1-28.

Hall, L. S., G.G. Grigg, M. Craig, K. Besar, S. Isa, M. Wahab \& M.T. Abdullah (2004). Biogeography of fruit bats in Southeast Asia. Sarawak Museum Journal 80: 191-284.

Klich, M (2002). Identification of Common Aspergillus Species. Centraalbureau voor Schimmelcultures, Utrecht, Netherland, $116 \mathrm{pp}$.

Payne, J., C.M. Francis \& K. Philipps (1985). A Field Guide to the Mammals of Borneo. Sabah Society: Kota Kinabalu.

Seelan, S.S.J., F.A. Anwarali, M. Sepiah \& M.T. Abdullah (2008). Bats (Chiropteran) reported with Aspergillus species from Kubah National Park, Sarawak, Malaysian Borneo. Journal of Tropical Biology and
Conservation 4(1): 81-97.

Raper, K.B. \& D.I. Fennell (1965). The Genus Aspergillus. Williams and Wilkins, Baltimore, 686pp.

Zdenek, H. (2004). An annoted checklist of pathogenic microorganisms associated with migratory birds. Journal of Wildlife Diseases 40(4): 639-659 